\title{
Effect of diagenetic recrystallization on the strength of planktonic foraminifer tests under compression
}

\author{
PAUL N. PEARSON ${ }^{*}, 1$, SAM L. EVANS ${ }^{2} \&$ JAMES EVANS ${ }^{1}$ \\ ${ }^{1}$ School of Earth and Ocean Sciences, Cardiff University, Main Building, Park Place, Cardiff CF10 3AT, UK \\ ${ }^{2}$ Cardiff School of Engineering, Cardiff University, Queen's Buildings, The Parade, Cardiff CF24 3AA, UK \\ *Corresponding author (e-mail: pearsonp@cardiff.ac.uk)
}

\begin{abstract}
We present the results of experiments to measure the brittle failure of fossil planktonic foraminifer tests under compression. We compare two upper Eocene species of contrasting morphology, Cribrohantkenina inflata (Howe, 1928) and Turborotalia cerroazulensis (Cole, 1928) in both well-preserved material from the Kilwa Group of Tanzania and recrystallized material from ODP Site 865, central Pacific Ocean. Well-preserved tests were several times stronger than recrystallized tests. Turborotalia cerroazulensis was stronger than $C$. inflata in both the well-preserved and recrystallized material.
\end{abstract}

KEYWORDS: foraminifera, diagenesis, Tanzania, ODP Site 865

SUPPLEMENTARY MATERIAL: All compression testing data are available at http://www.geolsoc.org. $u k / S U P 18790$

Gold Open Access: this article is published under the terms of the CC-BY 3.0 license.

\section{INTRODUCTION}

The calcite tests of foraminifera are produced in vast numbers by the ocean plankton and benthos and can comprise a significant component of marine sediments (Schiebel, 2002). The presence of tests in the sediment affects physical properties including porosity, compressibility, sonic velocity and the likelihood of failure under shear stress (Demars, 1982). Tests may be preserved intact and near pristine in the sediment for tens of millions of years (Bown et al., 2008), but they can also suffer a variety of diagenetic processes including recrystallization and mineral infilling/overgrowth (Hemleben et al., 1989). Tests may also be fragmented as a result of dissolution in the water column or sea floor, or by mechanical stresses during burial diagenesis (Hemleben et al., 1989). Johnson et al. (1977) showed that test fragmentation caused by sea-floor dissolution can affect sediment physical properties. Grützner \& Mienert (1999) discussed the role of burial diagenesis on the compaction of deep-sea carbonates, focusing on the role of cementation (overgrowth and infilling) of microfossils. Fabricius (2003) suggested that recrystallization of foraminifer tests could also affect sediment properties and compaction rates.

Diagenetic recrystallization of foraminifer tests can affect their isotopic and chemical composition and so bias palaeoclimate proxies (Pearson et al., 2001; Sexton et al., 2006; Pearson \& Burgess, 2008). The original biogenic textures differ among the various types of foraminifer. Here we focus on macroperforate planktonic foraminifera because they are very abundant, sometimes sediment-forming, and are frequently used in climate proxy work. The typical biogenic texture consists of irregular microgranules of calcite less than $0.1 \mu \mathrm{m}$ in diameter which are cemented together to form a solid test wall (Blow, 1979, p. 320) that is punctuated by circular pore channels connecting the inner and outer surfaces (Fig. 1a-b). The overall test morphology comprises a series of chambers added sequentially in life in a spiral arrangement, with each chamber connected to the next by a foramen and the last chamber opening in an aperture. Chamber shape varies from species to species and may be flattened and compressed or inflated and globular. Tests frequently display additional surface ornamentation, such as peripheral keels or spines.

In sediments that are millions of years old, this original biogenic texture is frequently found to be modified by fine-scale recrystallization in which the broad features of the test are retained but the wall consists of blocky crystallites, typically about $1 \mu \mathrm{m}$ in diameter (Fig. 1c-d). This is visible on the surface but is also pervasive through the test wall. In such cases, the test surface is no longer smooth and reflective and the original translucency is lost, presumably because light is scattered more efficiently by diagenetic crystallites than it is by biogenic microgranules. This accounts for the so-called 'glassy' versus 'frosty' appearance of well-preserved and recrystallized tests under the reflected light microscope (Sexton et al., 2006). The recrystallized condition is the norm in carbonate oozes and chalks although tests are often well preserved in clay-rich sediments, possibly because their impermeability prevents continuous reaction with circulating pore fluids over long periods of time.

When manually crushing tests under glass slides to investigate internal wall textures, we noticed that well-preserved and recrystallized tests have markedly different mechanical strength. Wellpreserved specimens can be difficult to break, often snapping with an audible crack only after significant pressure is applied. Recrystallized tests, in contrast, tend to be more fragile and often crumble easily when stress is applied. Here we present the results of some simple mechanical fracturing experiments using a compression testing machine to measure the forces involved and compare the effect of recrystallization and test morphology on strength under compression. Our method may prove useful in future studies of the effect of ocean acidification on foraminiferal tests which may cause thinning and reduction in strength (e.g. de Moel et al., 2009). 
a

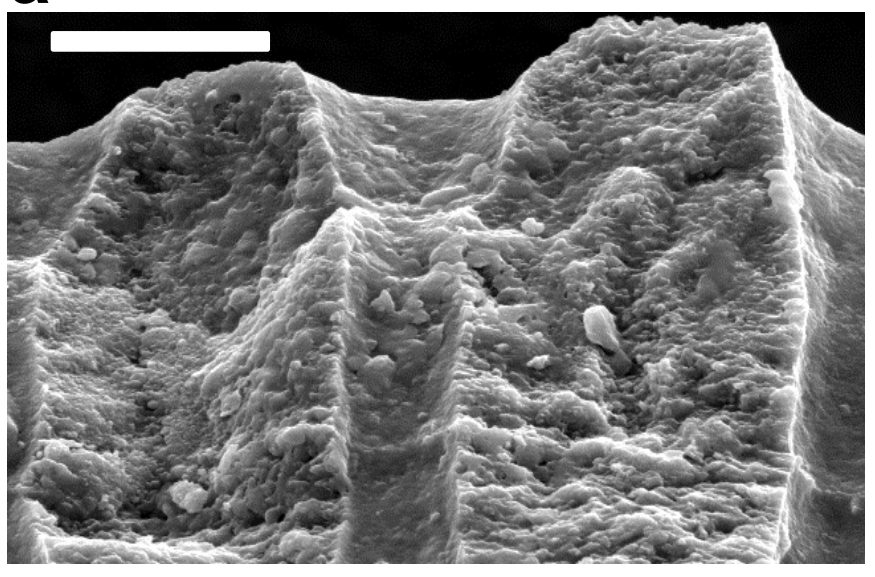

C

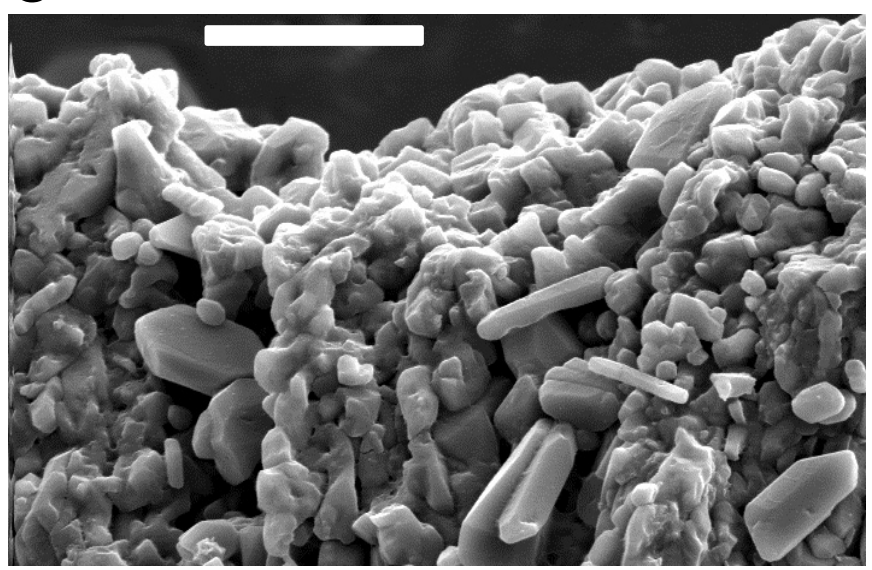

b

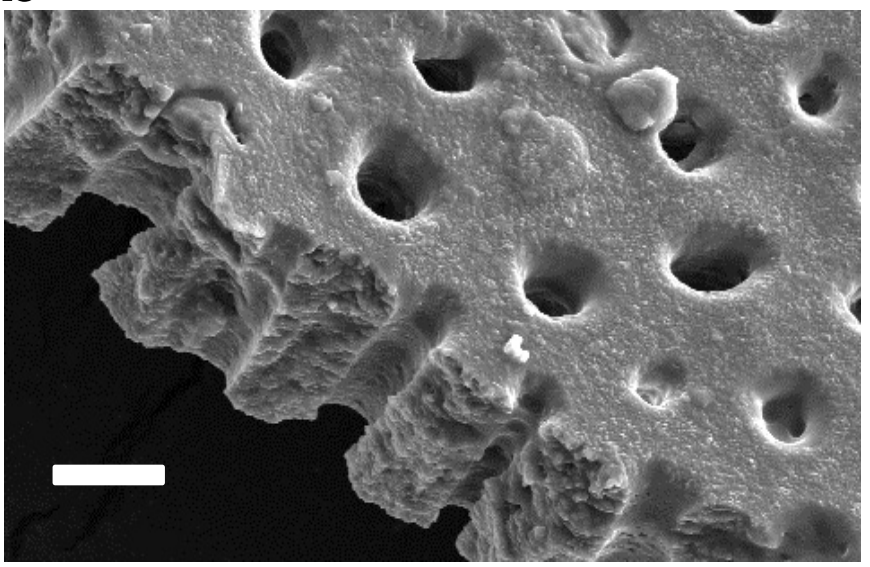

d

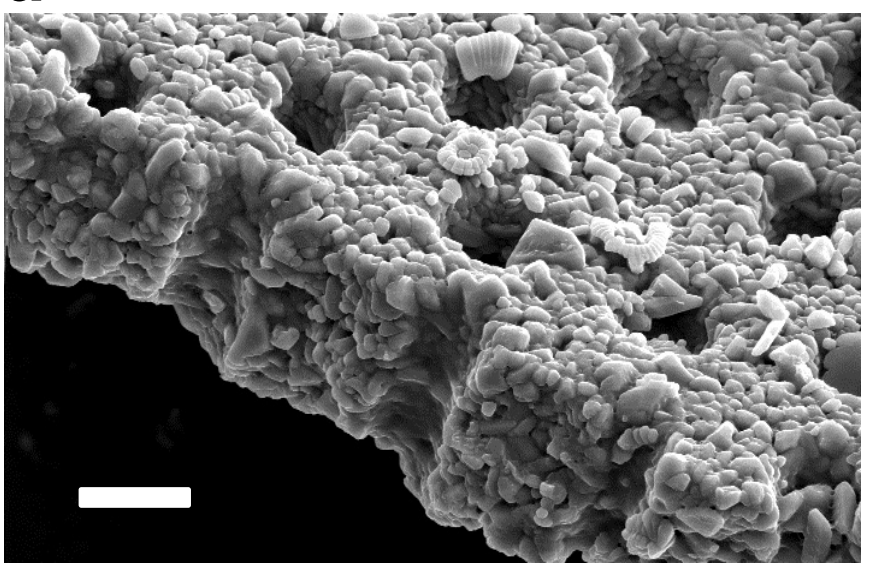

Fig. 1. Wall textures of well-preserved and recrystallized upper Eocene planktonic foraminifera. Specimens were broken under a glass slide to reveal the internal textures: (a) well-preserved Turborotalia cerroazulensis, TDP Site 17; (b) well-preserved Cribrohantkenina inflata, TDP Site 17; (c) recrystallized T. cerroazulensis, ODP Site 865; (d) recrystallized C. inflata, ODP Site 865. All scale bars $5 \mu \mathrm{m}$.

\section{MATERIAL AND METHODS}

We selected two samples from upper Eocene Biozone E15/16 (both approximately 34Ma): one well-preserved ('glassy'; Tanzania Drilling Project [TDP] Site 17; Nicholas et al., 2006) and the other pervasively recrystallized ('frosty'; Ocean Drilling Program [ODP] Site 865; Shipboard Scientific Party, 1993). Specimens were extracted from the matrix by washing over a sieve without the use of an ultrasonic bath. From each sample we selected approximately 15 tests of Cribrohantkenina inflata and 90 tests of Turborotalia cerroazulensis for destructive testing. Specimens were chosen only if they showed no visible sign of surface cracking or mechanical damage, although small-scale fractures would be impossible to see under the light microscope. The two species were chosen for their contrasting morphology. Cribrohantkenina inflata has a large, inflated final chamber that is approximately spherical in shape. This species was mounted on its side, the intention being to test the strength of the final chamber (Fig. 2a). Turborotalia cerroazulensis has an anguloconical morphology with a relatively flat spiral side and multiple conical chambers. When mounted on its spiral side, the final chamber is the highest, followed by the penultimate chamber and so on (Fig. 2b).

The maximum diameter of each specimen was measured using a graticule. Specimens were then mounted on a steel load plate using a thin coat of water soluble glue. The load plate was placed in a Losenhausen servohydraulic testing machine with a $5 \mathrm{~N}$ Interface S-beam load cell. During a typical experimental run the load cell assembly descends towards the load plate until it makes contact with the foraminifer test at which point it begins to register a force. The force gradually increases as the assembly continues to descend until the first mechanical failure $\left(\right.$ Fail $\left._{1}\right)$ when the force suddenly reduces and the load cell springs forward to make contact with a second point of resistance. The force begins to rise again until there is a second mechanical failure $\left(\mathrm{Fail}_{2}\right)$, and so on. Eventually the load cell comes into close contact with the load plate with just a crushed residue in between, whereupon the force registered climbs continuously until an automatic cut-off terminates the run. This cut-off was 


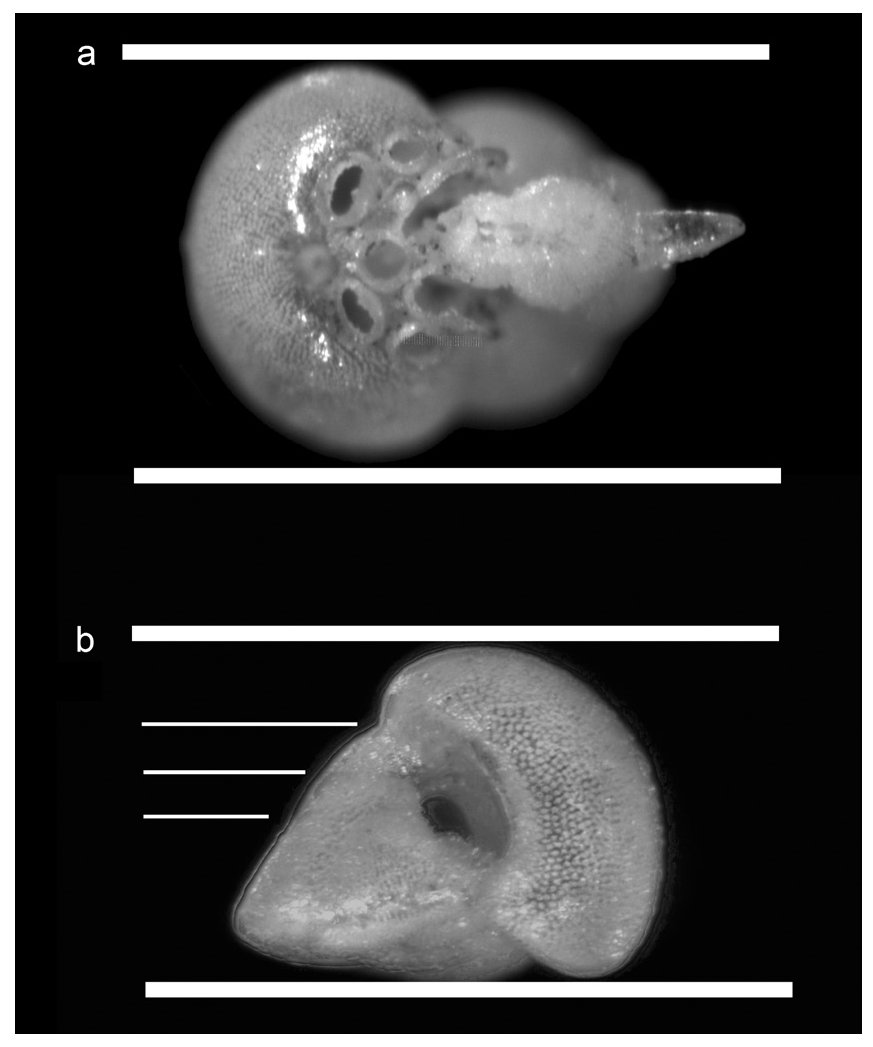

Fig. 2. Schematic figure showing representative tests of the two species in crush position (well-preserved specimens from Tanzania). (a) Cribrohantkenina inflata. Note final chamber in contact with load plate (represented by bottom bar) and load cell (top bar). (b) Turborotalia cerroazulensis. Note final chamber in contact with load plate (bottom bar) and load cell (top bar). Thin bars represent heights of earlier chambers of the final whorl that usually crush in succession. (Note: same specimen as illustrated by Wade \& Pearson, 2008, fig. 2.)
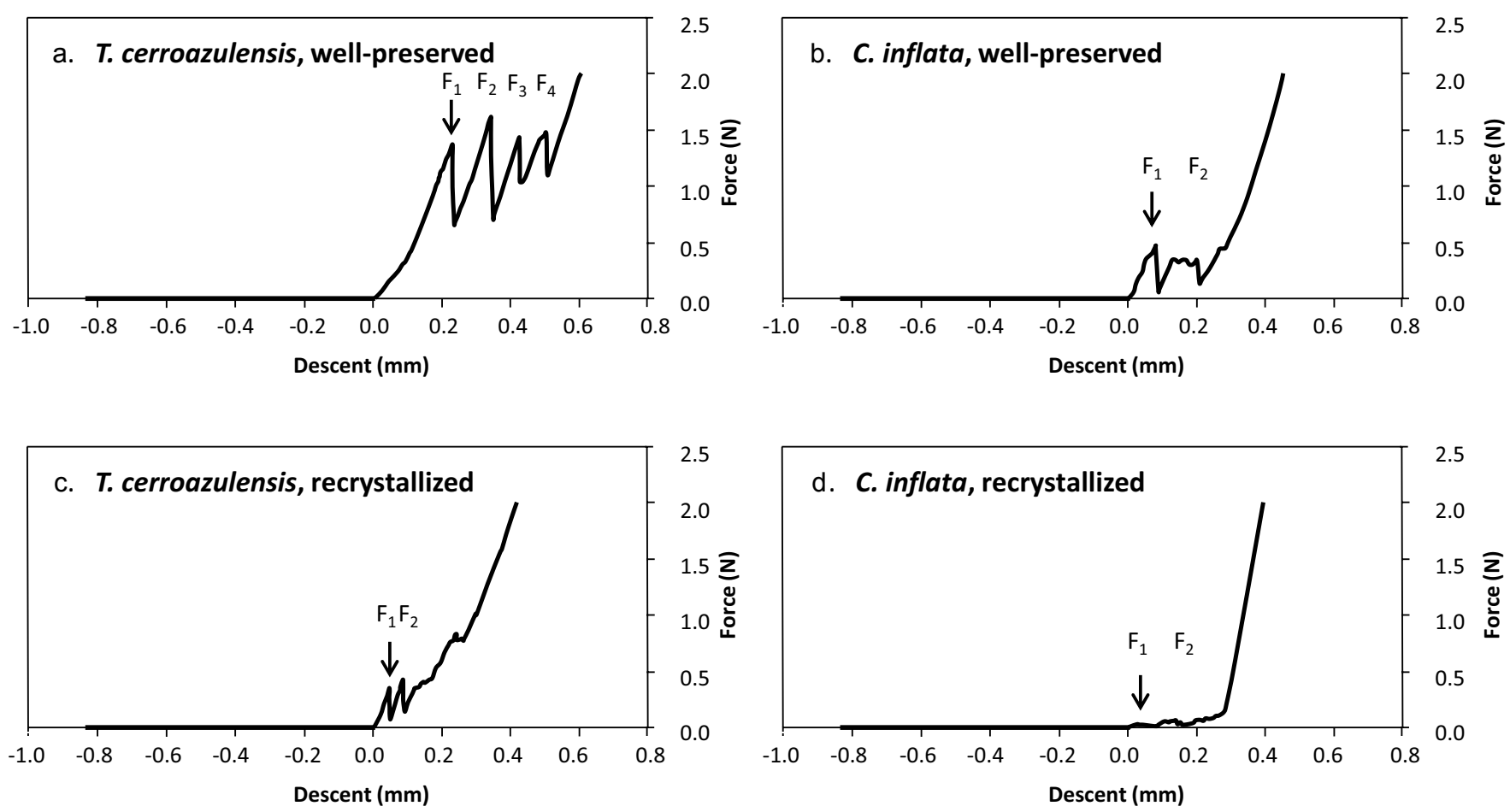

Fig. 3. Examples of experimental runs. The distance of load cell descent at which a force began to register is set at 0 . The point of first failure ( Fail $_{1}$ ) is the point at which a reduction in force is first detected (vertical arrows). 
Table 1. Summary statistics

\begin{tabular}{lccc}
\hline Species/preservation/first or second failure & Mean force $(\mathrm{N})$ at mechanical failure & Standard deviation (N) & Coefficient of variation \\
\hline T. cerroazulensis well-preserved (first failure) & 0.82 & 0.37 & 0.25 \\
C. inflata well-preserved (first failure) & 0.44 & 0.15 & 0.45 \\
T. cerroazulensis recrystallized (first failure) & 0.29 & 0.04 & 0.50 \\
C. inflata recrystallized (first failure) & 0.08 & 0.39 & 0.54 \\
T. cerroazulensis well-preserved (second failure) & 1.03 & 0.38 \\
\hline
\end{tabular}
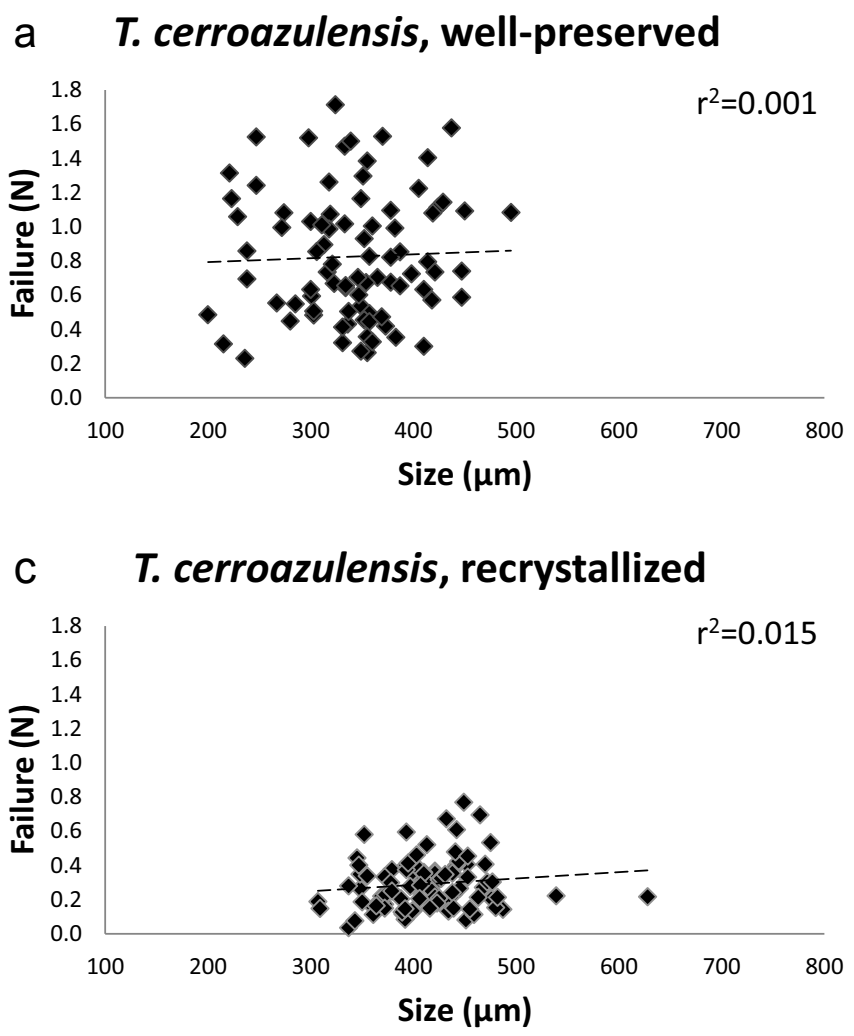
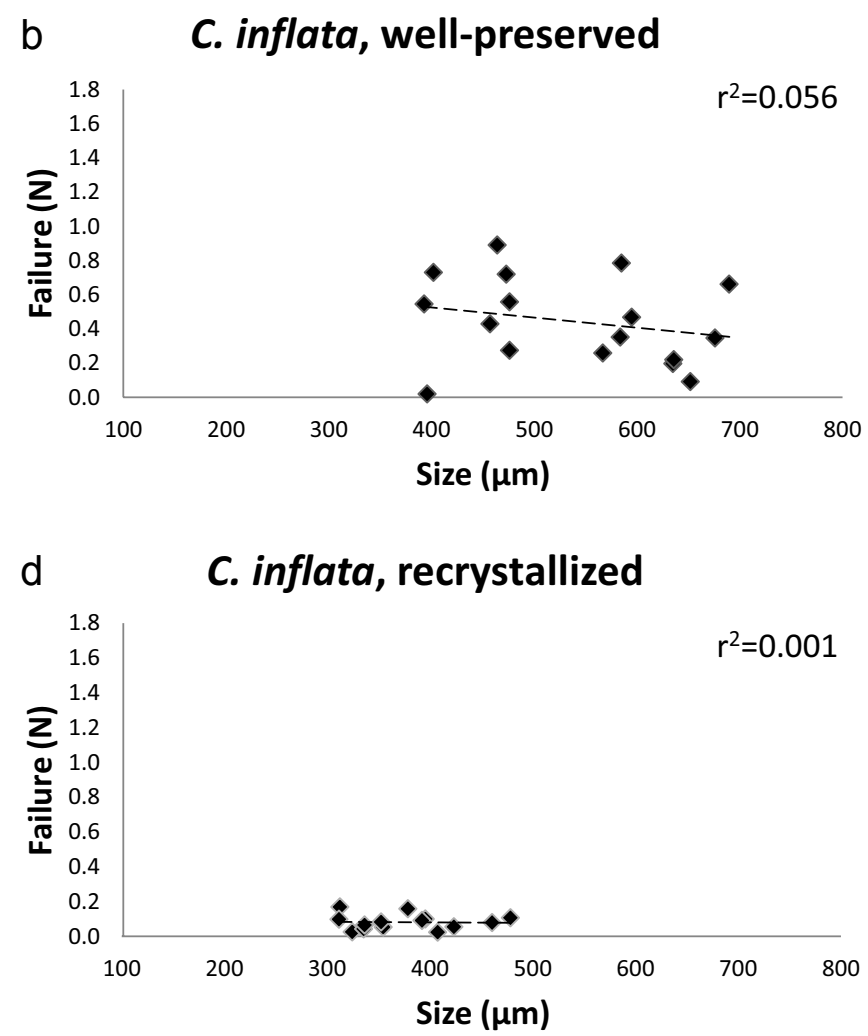

Fig. 4. Force at failure $(\mathrm{N})$ versus size for the four categories of test investigated. No significant correlation with size exists in any case.

initially set at $1.5 \mathrm{~N}$ but was later increased to $2 \mathrm{~N}$ as the experimental runs progressed.

\section{RESULTS}

A graphical output showing force against distance descended by the load cell assembly was plotted for each experimental run. Representative examples of these are shown in Figure 3. Wellpreserved $T$. cerroazulensis tended to show a saw-tooth pattern in which the final chamber was fractured first, followed by the penultimate chamber and so on, with up to four distinct failures being recorded (Fig. 3a). In contrast, because of its large spherical final chamber, well-preserved $C$. inflata tended to show a single peak representing failure of the final chamber followed by a complicated crush pattern as the rest of the test was destroyed (Fig. 3b). In a few instances in the $C$. inflata runs there was a sustained interval in which a significant force remained fairly constant as the load cell assembly descended. We interpret this as due to tilting or rolling of the spheroidal final chamber as it reoriented under pressure from the load cell. Eventually in those instances the force would rise again and failure would occur. The style of mechanical failure differs markedly between the wellpreserved and recrystallized tests, as shown by contrasting Figure $3 \mathrm{c}-\mathrm{d}$ with Figure $3 \mathrm{a}-\mathrm{b}$. The well-preserved material tended to show well-defined peaks which we interpret as the breakage of successive chambers, whereas the recrystallized material usually shows a less regular pattern with more numerous and poorly defined peaks and less abrupt decreases in force, which we attribute to a succession of small mechanical failures (i.e. crumbling of the chambers).

Our main aim was to measure the force required to crack a test, that is, the force at Fail 1 . The data are divided into four categories: (1) well-preserved T. cerroazulensis, (2) well-preserved C. inflata, (3) recrystallized T. cerroazulensis and (4) recrystallized $C$. inflata. We also measured the force at second failure, $\mathrm{Fail}_{2}$, for well-preserved $T$. cerroazulensis only. The mean, standard deviation and coefficient of variation for each category are given in Table 1. There are significant differences in mean test size between the two sites: T. cerroazulensis is smaller, on 


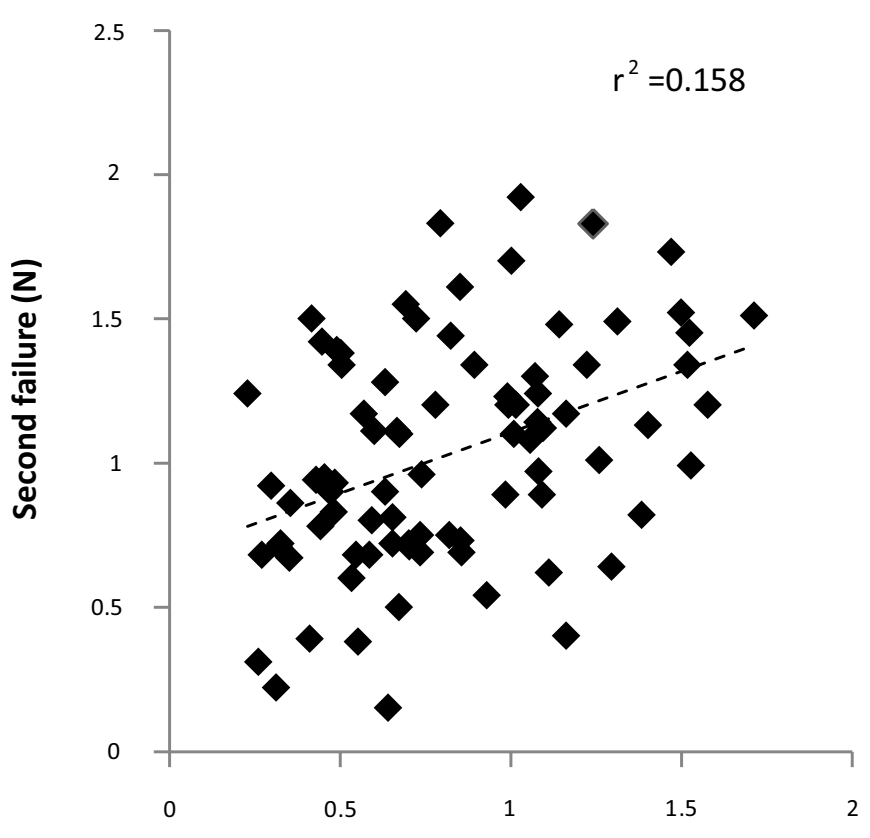

First failure (N)

Fig. 5. Force at first failure $\left(\mathrm{Fail}_{1}\right)$ versus force at second failure $\left(\mathrm{Fail}_{2}\right)$ for well-preserved Turborotalia cerroazulensis.

average, in Tanzania than it is at ODP Site 865, whereas $C$. inflata is larger. Within each category, there is no correlation between test diameter and force at Fail $_{1}$ (Fig. 4) so we proceeded to test for statistical differences between the four categories. As expected, results indicate that force at Fail $_{1}$ for well-preserved specimens of both $T$. cerroazulensis and $C$. inflata was significantly higher than for recrystallized specimens (2.8 and 5.5 times, respectively) and, within both preservation categories, force at $\mathrm{Fail}_{1}$ was significantly higher in T. cerroazulensis than $C$. inflata (1.9 and 3.6 times respectively; in all cases $P<<0.001$, two-tailed $t$-test).

We suggest that recrystallized tests are weaker than well-preserved ones because fractures propagate more easily between diagenetic crystallites in the test wall than they do through the closely packed structure of biogenic calcite (see Fig. 1c-d). We attribute the difference in strength between the two species mainly to the conical versus spherical shape of the final chamber in $T$. cerroazulensis by which the stress is more efficiently distributed through the test to the load plate. Differences in test wall thickness between the two species may also have been significant, but our attempts to measure this from the fractured residues proved inconclusive. Our results show that $C$. inflata weakens proportionally more in diagenesis than does $T$. cerroazulensis, despite there being no obvious difference in the recrystallization texture. This may also be due to the morphology: $C$. inflata presents a curved spherical surface to the load cell which is very easily caved in, whereas $T$. cerroazulensis requires the formation of longer fracture pathways to fail.

A degree of natural variability and variation between experimental runs was expected but we were surprised by the large spread of values for force at Fail 1 in well-preserved tests which, in some instances, fractured at very low applied stress.
The coefficients of variation for well-preserved and recrystallized tests are very similar for both species. We speculate that this may be because of unseen cracks or weaknesses, although the data do not clearly fall into two categories corresponding to cracked and whole tests, respectively. To further investigate this issue we compared force at first $\left(\right.$ Fail $\left._{1}\right)$ and second $\left(\right.$ Fail $\left._{2}\right)$ failure in the well-preserved T. cerroazulensis runs (Fig. 5). If the variation is related to differences in the inherent strength of individual tests we would expect a strong correlation, but if it is caused by random weaknesses, such as micro-cracks, we would expect no correlation. The second chambers were found to be slightly stronger, with a mean force at $\mathrm{Fail}_{2}$ of $1.03 \mathrm{~N}$ compared to $0.82 \mathrm{~N}$ at Fail $1(P \ll 0.001$, two-tailed $t$-test $)$. The strengths at Fail ${ }_{1}$ and $\mathrm{Fail}_{2}$ are indeed positively correlated, but with much scatter $\left(r^{2}=0.158\right)$. Hence although some component of the variability can be explained by some tests being stronger than others (perhaps due to variations in test thickness) there is still much unexplained variation.

The only other studies that we are aware of in which foraminifer tests were individually tested under compression are by Wetmore (1987) and Wetmore \& Plotnick (1992) on a variety of modern (recently living) benthic foraminifera from various families. The results of these studies are similar to ours for well-preserved specimens except that most of the benthic species are stronger, being more compact and thick-walled, and a weak positive correlation with size was found. Like us, Wetmore (1987) reported a surprisingly wide range of crushing force for tests of the same species. For example, Elphidiella hannai (Cushman \& Grant, 1927) has a mean crushing force of $1.67 \mathrm{~N}$ but a wide range from $0.26 \mathrm{~N}$ to $3.78 \mathrm{~N}$ with a large standard deviation of $0.84 \mathrm{~N}$ and coefficient of variation of about 0.5 (similar to our results in Table 1).

\section{CONCLUSION}

Well-preserved foraminifer tests are several times stronger under compression than recrystallized tests of the same species. Test morphology is also important: the anguloconical T. cerroazulensis is stronger under compression than the spherical final chamber of C. inflata both when well-preserved and recrystallized. These results help emphasize the difference between 'glassy' and 'frosty' preservation states as recognized qualitatively by visual inspection and in SEM and suggest a possible avenue for determining the degree of recrystallization of a given sample. Our results support the suggestion of Fabricius (2003) that, for marine sediments in which foraminifer tests and other carbonate microfossils are a significant component, micron-scale recrystallization could affect compaction rates during burial diagenesis and hence bulk sediment physical properties.

\section{ACKNOWLEDGEMENTS}

The writing of this work was funded through the UK Ocean Acidification Research Programme (Natural Environment Research Grant NE/H017518/1 to PNP). We thank Richard Kozdon and Pincelli Hull for insightful reviews, and Hull for suggesting the comparison presented in Figure 5.

Manuscript received 27 November 2013

Manuscript accepted 12 August 2014

Scientific editing by Bridget Wade. 


\section{REFERENCES}

Blow, W.H. 1979. The Cainozoic Globigerinida (3 vols). E.J. Brill, Leiden, 1413pp.

Bown, P.R., Dunkley Jones, T. et al. 2008. A Paleogene calcareous microfossil Konservat-Lagerstätte from the Kilwa Group of coastal Tanzania. Geological Society of America Bulletin, 120: 3-12.

Demars, K.R. 1982. Unique engineering properties and compaction behavior of deep-sea calcareous sediments. In Demars, K.R. \& Chaney, R.C. (Eds), Geotechnical Properties, Behavior, and Performance of Calcareous Soils. American Society for Testing and Materials, Baltimore, 97-112.

Fabricius, I.L. 2003. How burial diagenesis of chalk sediments controls sonic velocity and porosity. American Association of Petroleum Geologists Bulletin, 87: 1755-1778.

Grützner, J. \& Mienert, J. 1999. Physical properties changes as a monitor of pelagic carbonate diagenesis: an empirically derived diagenetic model for Atlantic Ocean basins. American Association of Petroleum Geologists Bulletin, 83: 1485-1501.

Hemleben, C., Spindler, M. \& Anderson, O.R. 1989. Modern Planktonic Foraminifera. Springer-Verlag, New York, 363pp.

Johnson, T.C., Hamilton, E.L. \& Berger, W.H. 1977. Physical properties of calcareous ooze: control by dissolution at depth. Marine Geology, 24: $259-277$.

de Moel, H., Ganssen, G.M., Peeters, F.J.C., Jung, S.J.A., Kroon, D., Brummer, G.J.A. \& Zeebe, R.E. 2009. Planktic foraminiferal shell thinning in the Arabian Sea due to anthropogenic ocean acidification? Biogeosciences, 6: 1917-1925.

Nicholas, C.J., Pearson, P.N. et al. 2006. Stratigraphy and sedimentology of the Upper Cretaceous to Paleogene Kilwa Group, southern coastal Tanzania. Journal of African Earth Sciences, 45: $431-466$.

Pearson, P.N. \& Burgess, C.E. 2008. Foraminifer shell preservation and diagenesis: comparison of high latitude Eocene sites. In Austin, W.E.N. \& James, R.H. (Eds), Biogeochemical Controls on Palaeoceanographic Proxies. Geological Society, London, Special Publications, 303: 59-72.

Pearson, P.N., Ditchfield, P.W. et al. 2001. Warm tropical sea surface temperatures in the Late Cretaceous and Eocene epochs. Nature, 413: 481-487.

Schiebel, R. 2002. Planktonic foraminiferal sedimentation and the marine calcite budget. Global Biogeochemical Cycles, 11: 125-133.

Sexton, P.F., Wilson, P.A. \& Pearson, P.N. 2006. Microstructural and geochemical perspectives on foraminiferal preservation: 'Glassy' versus 'Frosty'. Geochemistry, Geophysics, Geosystems, 7: Q12P19, http:// dx.doi.org/10.1029/2006GC001291

Shipboard Scientific Party. 1993. Site 865. In Sager, W.W., Winterer, E.L., Firth, J.V. et al. Proceedings of the Ocean Drilling Program, Scientific Results, 143: 111-180.

Wade, B.S. \& Pearson, P.N. 2008. Planktonic foraminiferal turnover, diversity fluctuations and geochemical signals across the Eocene/Oligocene boundary in Tanzania. Marine Micropaleontology, 68: 244-255.

Wetmore, K.L. 1987. Correlations between test strength, morphology and habitat in some benthic foraminifera from the coast of Washington. Journal of Foraminiferal Research, 17: 1-13.

Wetmore, K.L. \& Plotnick, R.E. 1992. Correlations between test morphology, crushing strength, and habitat in Amphistegina gibbosa, Archaias angulatus, and Laevipeneroplis proteus from Bermuda. Journal of Foraminiferal Research, 22: 1-12. 